\title{
Phaeocystis globosa and the phytoplankton succession in the East Frisian coastal waters
}

\author{
J. Rahmel ${ }^{1}$, M. Bätje ${ }^{1}$, H. Michaelis ${ }^{1}$ \& U. Noack ${ }^{2}$ \\ ${ }^{1}$ Niedersächsisches Landesamt für Ökologie, Forschungsstelle Küste; \\ An der Mühle 5, D-26548 Norderney, Germany \\ ${ }^{2}$ Dr. U. Noack-Laboratorium für angewandte Biologie; \\ Richthofenstr. 29, D-31137 Hildesheim, Germany
}

\begin{abstract}
The phytoplankton succession and related abiotic variables were investigated within the frame of a monitoring programme. Results from 1985 to 1991 are presented. For the prymnesiophyte Phaeocystis globosa, an increase in the maximum annual abundance was observed. The appearance of this species in the phytoplankton succession followed an annually recurrent pattern. Among the starting conditions for the bloom, a coincidence with the annual DIN/P maximum was most obvious. Quantitatively, temperature and salinity showed the lowest variability at the onset of the blooms. Nutrient uptake during the increasing phase of the bloom appeared to affect nitrate concentrations more significantly than those of ammonia and phosphate.
\end{abstract}

\section{INTRODUCTION}

Since the end of the nineteen-seventies, the population dynamics of the prymnesiophyte Phaeocystis globosa received accentuated attention along the southern coast of the North Sea (Bätje \& Michaelis, 1986; Weisse et al., 1986; Cadee \& Hegeman, 1986; Lancelot et al., 1987). It was assumed that the more frequently-occurring blooms of this species indicated a eutrophication-caused change in the pelagic communities of the coastal waters. The hypothesis that the increase in nutrient input to the marine environment might have enhanced $P$. globosa blooms has also been emphasized for other geographical regions (Al-Hasan et al., 1990). In the Netherlands, trends in the occurrence of $P$. globosa blooms and their relation to coastal eutrophication have been continuously observed since the 'seventies (Cadée \& Hegeman, 1991; Riegman et al., 1990). In these investigations, a relation between riverine nutrient input and phytoplankton biomass or bloom magnitude, respectively, was found - which is at least plausible for the western part of the Dutch Wadden Sea (Cadée \& Hegeman, 1986; Riegman et al., 1992). Available information for the German coastal zone is mainly based on results gained from short observation periods in the 'seventies or early 'eighties (Weisse et al, 1986; Bätje \& Michaelis, 1986; Eberlein et al., 1985). A continuous time-series which provides information on recent developments is not reported for the German coastal zone. Some results from this area concerning the role of $P$. globosa in the annual phytoplankton succession and its relation to the physico-chemical environment from the period 1985-1991 are presented in this paper. 


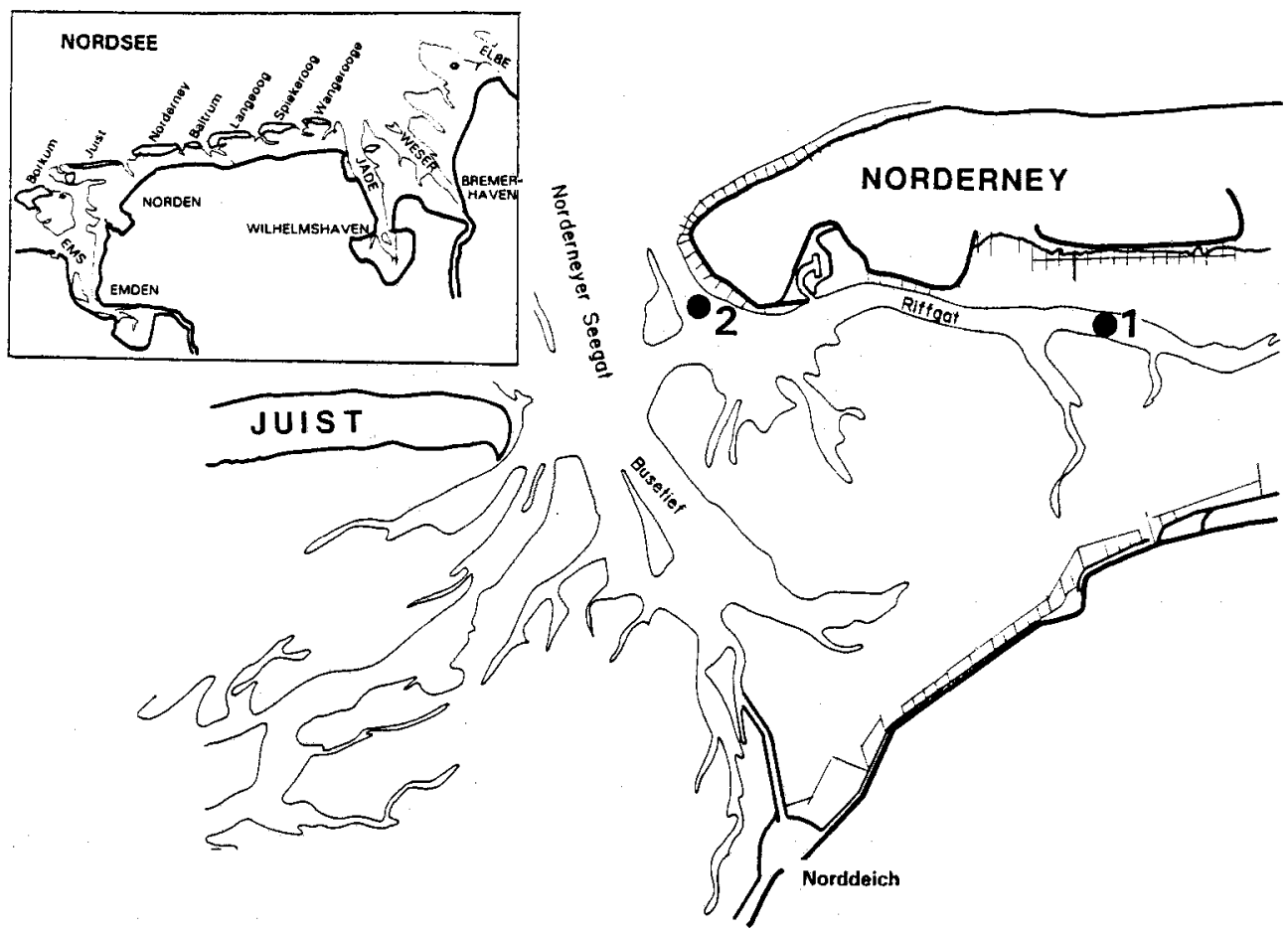

Fig. 1. Location of sampiing sites

\section{MATERIAL AND METHODS}

The results presented here are derived from two permanent phytoplankton monitoring stations in the area of Norderney, East Frisian Islands, Germany (Fig. 1). Sampling frequency was weekly during the vegetation period, and fortnightly during the winter months. The water column at these locations is vertically mixed due to tidal action. Samples were taken at high tide from surface water and immediately analyzed for temperature and salinity. Subsamples were filtered and stored for the determination of the content of suspended matter. Nutrient analysis was conducted according to the methods of Grasshoff et al. (1983). Colonies of P. globosa and large phytoplankton cells were counted in a tray as described in Newell \& Newell (1963). The quantification of the smaller phytoplankton under the inverted microscope followed the method of Utermöhl (1958).

\section{RESULTS}

For an assessment of the development and magnitude of $P$ globosa blooms, data have been available since 1982. Taking into account the maximum annual abundance of the colonial phase of the species life cycle, an increase can be detected (Fig. 2). In particular the strong blooms in 1989 and 1991 with abundances of 38500 and 49000 colonies $\mathrm{l}^{-1}$, respectively, reinforce this tendency. For single cells, this increase is less pronounced. The period during which mass developments (abundances of more than 


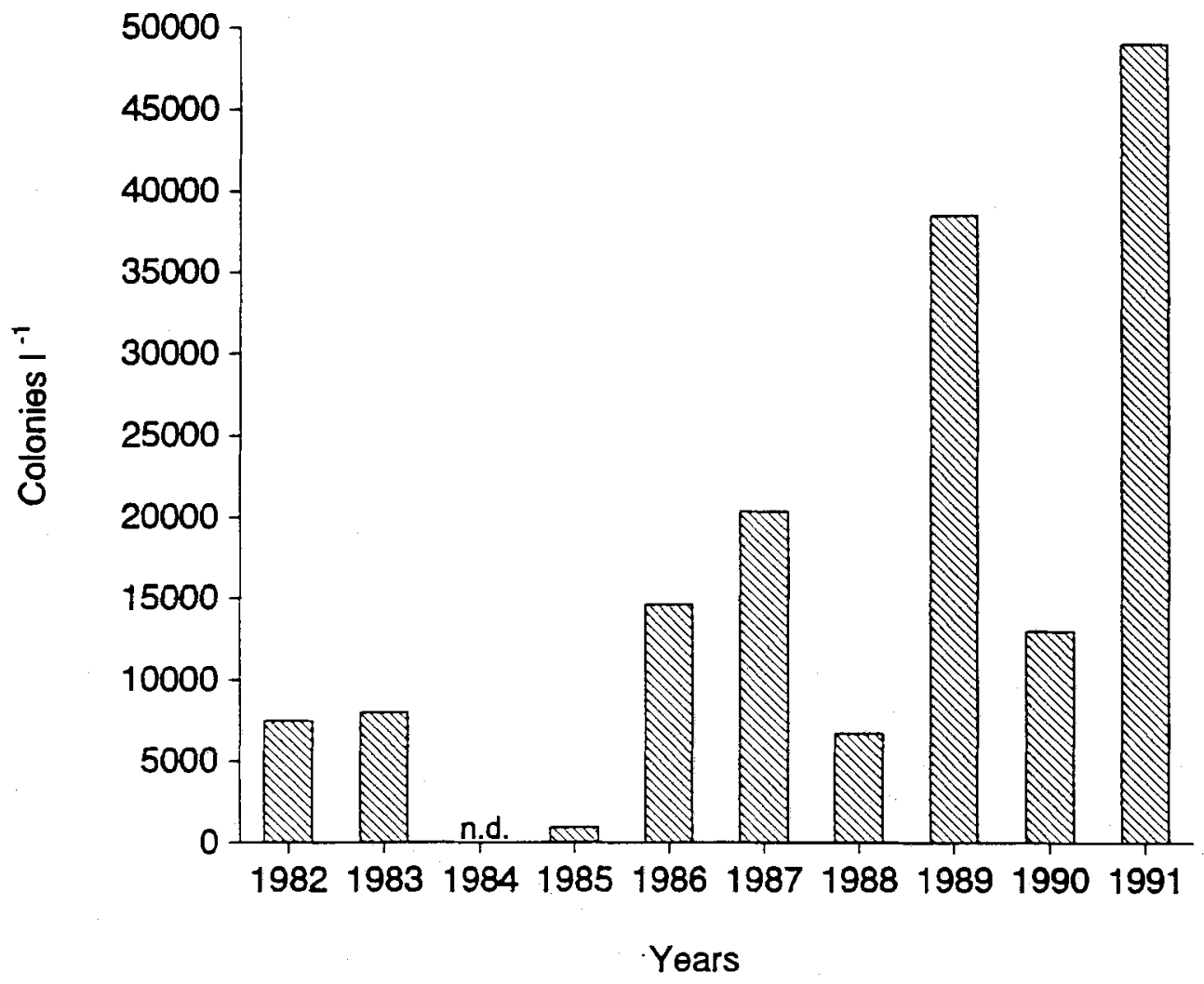

Fig. 2. Increase in the maximum annual abundance of $P$. globosa

1000 cells $\mathrm{ml}^{-1}$ ) of the species can be observed varies between 27 and 68 days per year. From 1982 to 1991 no significant change in the duration of the bloom period could be observed.

The anaiysis of the annual cycie of the phytoplankton reveals a pattern which is displayed in Figure 3. The P. globosa spring bloom either follows, or intersects with, the spring diatom bloom. A minor diatom bloom follows the P. globosa bloom. This sequence of phytoplankton groups can be found almost every spring. During May and June higher abundances of the heterotrophic dinoflagellate Noctiluca scintillans may appear. The remaining part of the annual cycle is less regular. For the first diatom bloom, a considerable year-to-year variability concerning the dominant species could be stated (Table 1). Brockmanniella brockmannii and Skeletonema costatum are the more frequently occurring species. Additionally, during the second diatom bloom different species may become dominant Among these is Asterionella glacialis, for the majority of the survey years. Autumn diatom blooms are not a common feature of the annual cycle. They may appear during some years, however. The $P$. globosa spring bloom usually starts from the beginning of April to early May (Table 2). The annual maximum is mainly found in early May Further mass developments of this species also occur during summer. Their magnitude is in general, less significant than that of the first peak 

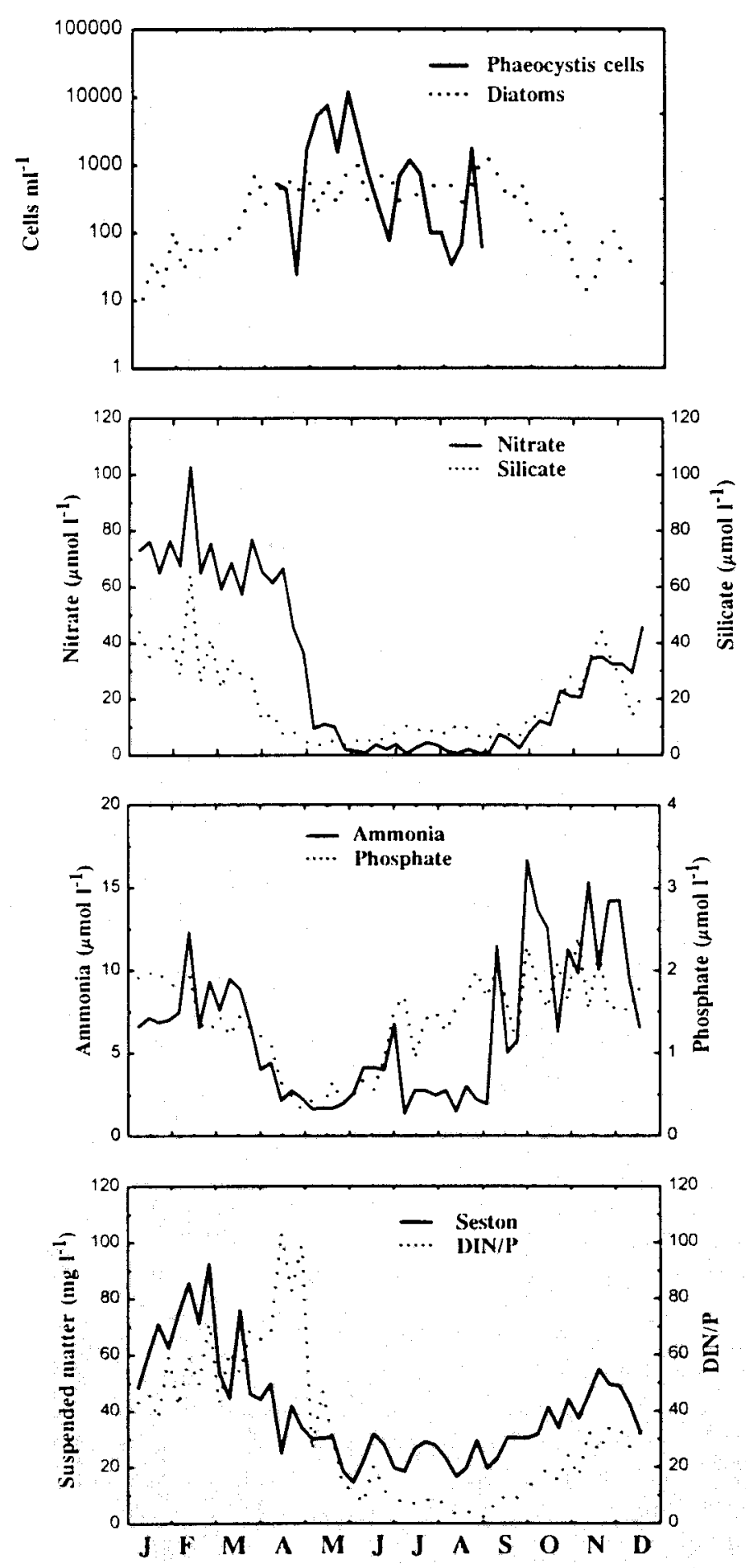
Table 1. Dominant species during the first diatom blooms in the annual cycle at the Norderney plankton survey station, 1985-1991

\begin{tabular}{|lll|}
\hline Year & \multicolumn{1}{c|}{ First diatom bloom } & Second diatom bloom \\
\hline \multirow{2}{*}{1985} & Odontella aurita & Cerataulina bergonii \\
& Brockmanniella brockmannii & Asterionella glacialis \\
1986 & Thalassiosira minima & Skeletonema costatum \\
& Asterionella kariana & Nitzschia delicatissima \\
& Asterionella glacialis & Asterionella glacialis \\
& Brockmanniella brockmannii & Skeletonema costatum \\
& Skeletonema costatum & Asterionella glacialis \\
& Chaetoceros sp. & Rhizosolenia delicatula \\
1988 & Skeletonema costatum & Rhizosolenia sp. \\
& Brockmanniella brockmannii & Asterionella glacialis \\
1990 & No major bloom observed & \\
& Thalassiosira nordenskiöldii & Rhizosolenia sp. \\
1991 & Ditylum brightwellii & Nitzschia seriata \\
& &
\end{tabular}

Table 2. Variability of the initial conditions of the Phaeocystis bloom, 1985-1991. Only results from sampling dates right before and after the blooms onset are included. AVG = arithmetic mean, STD $=$ standard deviation, $\mathrm{V}_{\mathrm{r}}=$ relative variation coefficient $(\%)$. Concentrations of nutrients are given in umol $1^{-1}$

\begin{tabular}{|lrrrrr|}
\hline Variable & $\mathrm{n}$ & AVG & MEDIAN & STD & $\mathrm{V}_{\mathrm{r}}$ \\
\hline Week & 27 & 15.92 & 15.57 & 2.22 & 2.68 \\
Temperature & 27 & 9.52 & 10.10 & 2.00 & 4.04 \\
Salinity & 27 & 30.67 & 31.07 & 1.87 & 1.17 \\
Ammonia & 26 & 2.33 & 1.71 & 1.78 & 14.94 \\
Nitrate & 27 & 44.32 & 40.60 & 30.25 & 13.14 \\
Phosphate & 27 & 0.60 & 0.60 & 0.37 & 11.80 \\
Silicate & 26 & 8.02 & 4.89 & 10.01 & 24.48 \\
DIN/P & 27 & 129.01 & 79.00 & 135.53 & 20.22 \\
\hline
\end{tabular}

The course of the spring blooms is closely related to the annual dynamics of the physico-chemical environment. This relation still emerges in the generalizing scheme given in Figure 3. During winter, the cell numbers are low. The occurring species are mainly diatoms. Inorganic nutrients are available in high concentrations. From the median values of the DIN/P ratio and the molar ratio of silicate versus phosphate, nutrient conditions of DIN : Si : P of $49: 19.5: 1$ can be calculated. Along with the diatom spring bloom the concentrations of silicate, phosphate and ammonia decrease. Nitrate, however, is not as severely affected by this event. This causes the establishment of the annual maximum of the molar ratio of dissolved inorganic nitrogen compounds versus dissolved

Fig. 3. Phytoplankton succession and the relation to abiotic factors. The results presented are weekly median values from 1985 to 1991 
phosphate (DIN/P ratio). This maximum generally coincides with the start of the $P$. globosa bloom.

Along with the increase in the abundance of $P$. globosa goes a significant diminution of the nitrate concentrations. This consumption, combined with an increasing phosphate content during summer, results in low DIN/P ratios. Quantitatively, the initial environmental conditions for the $P$. globosa spring bloom proved to be rather variable. The results which are displayed in Table 2 show that the variability of its timing, as well as that of the temperature and salinity range, is moderate. The values for the nutrients show a deviation from the mean which is significantly higher.

More detailed information on the nutrient dynamics during the $P$. globosa spring blooms of several years is given in Figure 4. For this purpose, results received during the period between the start and the maximum of the bloom are pooled. The ammonia concentrations remain almost unaffected by the rising of the abundance of $P$. globosa. For nitrate and phosphate, a reduction is indicated by the regression line. In spite of this common trend, differences can be observed. Nitrate is almost depleted in the course of the mass development of $P$. globosa (Spearman rank order correlation: $r_{\mathrm{s}}=-0.596, \mathrm{n}=$ 55, p < 0.005). The concentrations can decrease by two orders of magnitude. The phosphate levels do not change as dramatically; the reduction to almost undetectable concentrations is not as common as with nitrate. During several years, phosphate even seems to recover at maximum abundances of $P$. globosa (Spearman rank order correlation: $\mathrm{r}_{\mathrm{s}}=-0.280, \mathrm{n}=55, \mathrm{p}<0.05$ ). The different behaviour of the two nutrients holds especially true for the years with strong blooms, like 1989 and 1991.

\section{DISCUSSION}

Between 1982 and 1991, a tendency to an increase in the magnitude of the P. globosa blooms could be observed. These results are to some extent in agreement with reports from the western Dutch Wadden Sea. Cadée \& Hegeman (1986) describe an increase in the abundance of $P$. globosa and in the duration of the blooms in the period 1974-1985. Concerning the development of the duration of the blooms, there is a difference between the results of both time-series. At Norderney, no prolongation could be detected. Based on the comparably short time series, however, it is difficult to conclude whether the observed increase in the bloom magnitude at the Norderney stations is able to be indicative of a long-term trend. It has further to be considered that the tendency is valid for the maximum abundances, which implies that the sampling frequency may have influenced the results. During 1982-1988, the actual maxima may have been missed while they were sampled in 1989 and 1991. Historical data on the abundance of P. globosa in the area of the East Frisian Islands are reported by Mielck (1932) and Wulff (1935). Maximum values given by these authors amount to 2300 or $1300-5640$ colonies $1^{-1}$, respectively. It is not clear, however, whether these values actually represent abundances at maximum bloom development. Despite these uncertainties the observed tendency should not be ignored but rather be considered as an indication of a change in the system.

Fig. 4. Decrease of dissolved nutrients during the growth phase of several P. globosa blooms. The regression line is calculated for pooled data from both stations. Symbols indicate different years from 1985 to 1991 
Phaeocystis globosa in East Frisian waters
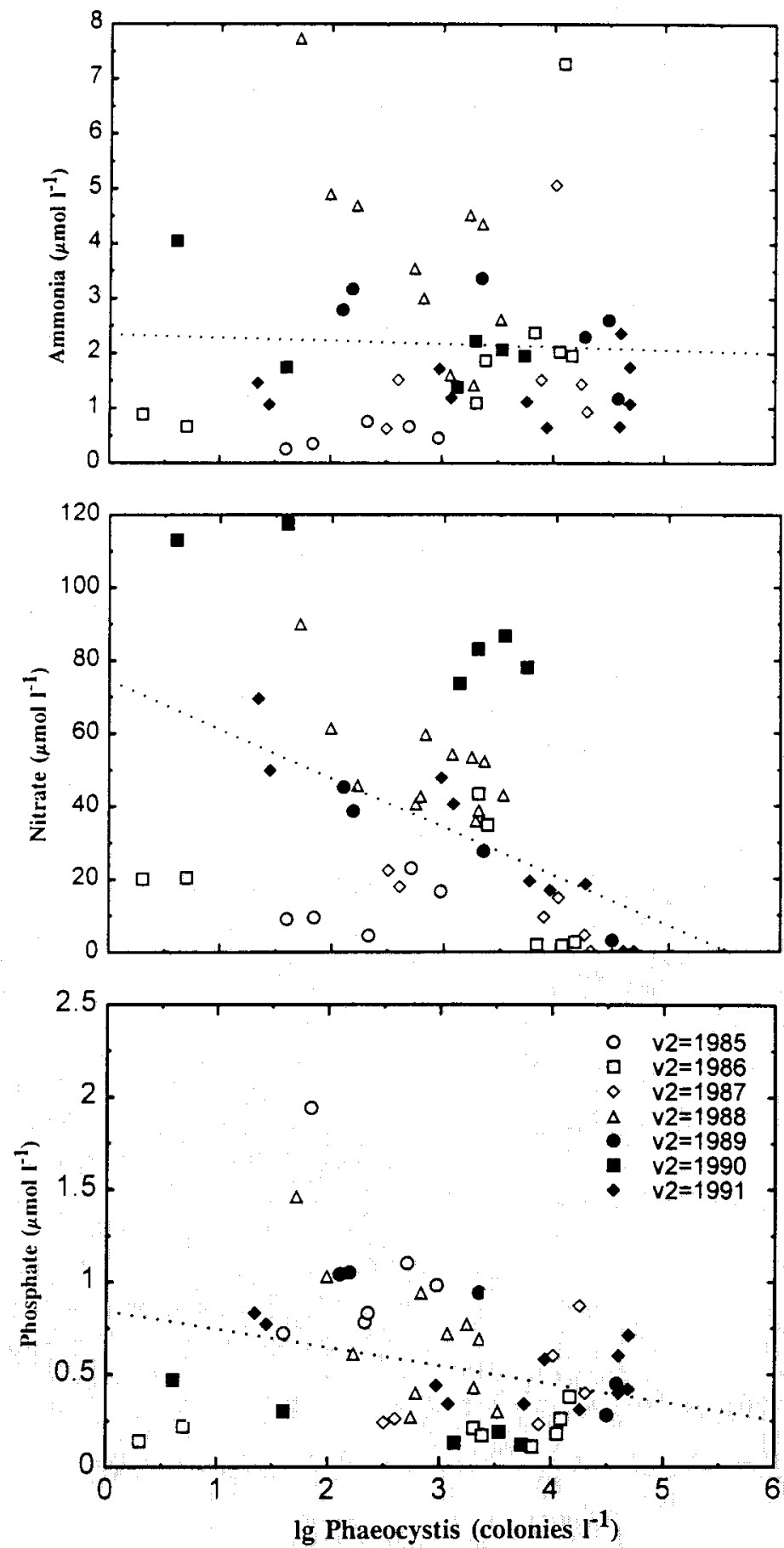
The coastal waters of the East Frisian Islands are tidally mixed all year round and show a broad salinity range. At the Norderney stations, salinities varying between 23.4 and $34.6 \%$ could be measured. This indicates that the stations are exposed to influences from different hydrographical regimes. Although an unpredictable series of events is rather to be expected in such an unstable environment, a recurrent pattern was observed - at least for the early stages of the annual cycle of the phytoplankton. This diatomP. globosa-diatom succession also occurs in Dutch and Belgian coastal waters (Cadée, 1986; Lancelot et al., 1991). Its annual appearance in the East Frisian coastal waters is very reliable for March-May. For the remaining part of the year, such a clear pattern in the annual cycle of the phytoplankton could not be observed. Cadée (1986) describes a generalized model of the annual phytoplankton cycle in the Marsdiep. It displays a threefold reiteration of the diatom- $P$. globosa sequence. This model does not seem to be valid for the Norderney stations.

The conditions which trigger the P. globosa blooms have to some extent been discussed by Weisse et al. (1986). Among them, the influence of organic substances either originating from the preceding diatom bloom or from terrestrial sources - has been considered. It was also assumed that certain nutrient or temperature conditions might be essential factors for the start of the mass development. So far, the role of terrigenous substances is still speculative, while the potential of $P$. globosa to extract phosphate from organic matter has been proven (Veldhuis et al., 1987; van Boekel \& Veldhuis, 1990). The role of temperature in the spring phytoplankton succession has also been mentioned by Cadée \& Hegeman (1986). According to their results, no relation could be detected between temperature and the onset of the spring increase of P. globosa. At Norderney, the temperatures at the start of the bloom ranged from 5.0 to $12.8^{\circ} \mathrm{C}$. Although the variability of the temperature conditions is low compared to that of the nutrients (Table 2), it has to be considered that the extreme values cover about one quarter of the annual temperature spectrum. These field observations are slightly different from results which Grimm \& Weisse (1985) received from laboratory studies. They found that $P$. globosa did not show any appreciable growth at temperatures lower than $7^{\circ} \mathrm{C}$. The influence of nutrients on the appearance of the species has been discussed by several authors (Bätje \& Michaelis, 1986; Veldhuis et al., 1986; Lancelot et al., 1991). Characteristic for all these descriptions is the observation of different concentrations of reactive silicate, phosphate, ammonia and nitrate. While the first three nutrients become significantly reduced during the first diatom bloom, nitrate concentrations are not affected that much. This oppositional development leads to elevated DIN/P levels.

As shown in the results, drastic changes in the concentrations of some dissolved inorganic nutrients occur during the P globosa bloom. The most pronounced deviation from the pre-bloom situation can yearly be observed for nitrate. This finding is also supported by the fact that the negative correlation between $P$. globosa abundance and nitrate concentration is closer than with other nutrients. Provided that nutrients are able to become limiting resources in the turbid waters of the Wadden Sea, a shortage of nitrate might be most probable during blooms of this phytoplankton species. Lancelot \& Mathot (1987) reported that its growth was N-limited during the spring bloom in Belgium coastal waters. This conclusion is supported by the results of Riegman et al. (1990), who detected a severe nitrogen limitation at the peak of the P. globosa bloom in the Marsdiep area, in the Netherlands. Other authors (Veldhuis et al,, 1986; Hesse et al., 1992) identified 
phosphate as the limiting nutrient. In the case of Veldhuis et al. (1986), this contradiction might be due to the fact that his conclusions are based on a method which is not a good indicator for phosphorus limitation in P. globosa blooms (van Boekel \& Veldhuis, 1990). Beyond the methodological problems, it has to be considered that both studies from the Dutch coastal waters were conducted in different marine environments. Veldhuis et al. (1986) worked at a greater distance from the coast, while Riegman et al. (1990) sampled at a station which was influenced by the nutrient cycles of the Wadden Sea. There, an enhanced $P$ supply due to remineralisation and resuspension might be expected. It has to be examined whether the result of the latter study can be extrapolated to the German Wadden Sea. As to the question whether or not nutrients can become limiting resources in this area at certain times of the year: this is still not solved, and further investigations on the topic are needed.

\section{LITERATURE CITED}

Al-Hasan, R. H., Ali, A. M. \& Radwan, S. S., 1990. Lipids, and their constituent fatty acids, of Phaeocystis sp. from the Arabian Gulf. - Mar. Biol. 105, 9-14.

Bätje, M. \& Michaelis, H., 1986. Phaeocystis pouchetii blooms in the East Frisian coastal waters (German Bight, North Sea). - Mar. Biol. 93, 21-27.

Boekel, W. H. M. van \& Veldhuis, M. J. W., 1990. Regulation of alkaline phosphatase synthesis in Phaeocystis sp. - Mar. Ecol. Prog. Ser. 61, 281-289.

Cadée, G. C. \& Hegeman, J., 1986. Seasonal and annual variation in Phaeocystis pouchetii (Haptophyceae) in the westernmost inlet of the Wadden Sea during the 1973 to 1985 period. Neth. J. Sea Res. 20 (1), 29-36.

Cadée, G. C. \& Hegeman, J., 1991. Historical phytoplankton data of the Marsdiep. - Hydrobiol. Bull. 24 (2), 111-118.

Eberlein, K., Leal, M. T., Hammer, K. D. \& Hickel, W., 1985. Dissolved organic substances during a Phaeocystis pouchetii bloom in the German Bight (North Sea). - Mar. Biol. 89, 311-316.

Grasshoff, K., Ehrhardt; M. \& Kremling, K., 1983. Methods of seawater analysis. Verl. Chemie, Weinheim, $419 \mathrm{pp}$.

Grimm, N. \& Weisse, T., 1985. Die Temperaturabhängigkeit des Wachstums von Phaeocystis pouchetii (Haptophyceae) in Batchkulturen. - Helgoländer Meeresunters. 39, 201-211.

Hesse, K.-J., Hentschke, U. \& Brockmann, U., 1992. A synoptic study of nutrient and phytoplankton characteristics in the German Wadden Sea with respect to coastal eutrophication. In: Marine eutrophication and population dynamics. Ed. by G. Colombo, I. Ferrari, M. Ceccherelli \& R. Rossi: Olsen \& Olsen, Fredensborg, 45-53 (25th European Marine Biology Symposium).

Lancelot, C. \& Mathot, S., 1987. Dynamics of a Phaeocystis dominated spring bloom in Belgian coastal waters. I.: Phytoplankton activities and related parameters. - Mar. Ecol. Prog. Ser. 37. 239-248.

Lancelot, C., Billen, G., Sournia, A., Weisse, T., Colijn, F., Veldhuis, M. J. W., Davies, A. \& Wassmann, P., 1987. Phaeocystis blooms and nutrient enrichment in the continental coastal zones of the North Sea. - Ambio 16 (1), 38-46.

Lancelot, C., Billen, G. \& Barth, H. (Eds), 1991. The dynamics of Phaeocystis blooms in nutrient enriched coastal zones. - Wat. Pollut. Res. Rep. 23, 1-106.

Mielck, W., 1932. Southern North Sea 1931. - Rapp. P.-v. Réun. Cons perm. int. Explor. Mer 81, $184-213$.

Newell, G. E. \& Newell, R. C., 1963. Marine plankton. Hutchinson Educational, London, 244 pp.

Riegman, R., Colijn, F, Malschaert, J. F. P., Kloosterhuis, H. T. \& Cadée, G. C., 1990. Assessment of growth rate limiting nutrients in the North Sea by the use of nutrient-uptake kinetics. - Neth. J. Sea Res. $26(1), 53-60$.

Riegman, R. Noordeloos, A. A. M. \& Cadée, G. C., 1992. Phaeocystis blooms and eutrophication of the continental coastal zone of the North Sea. - Mar. Biol. 112, 479-484. 
Utermöhl, H., 1958. Zur Vervollkommnung der quantitativen Plankton-Methodik. - Mitt. int. Ver. theor, angew. Limnol. 9, 1-38.

Veldhuis, M. J. W., Colijn, F. \& Venekamp, L. A. H., 1986. The spring bloom of Phaeocystis pouchetii (Haptophyceae) in Dutch coastal waters. - Neth. J. Sea Res. 20 (1), 37-48.

Veldhuis, M. J. W., Venekamp, L. A. H. \& Ietswaart, T., 1987. Availability of phosphate sources for blooms of Phaeocystis pouchetii (Haptophyceae) in the North Sea: impact of the river Rhine. Neth. J. Sea Res. 21 (3), 219-229.

Weisse, T., Grimm, N., Hickel, W. \& Martens, P., 1986. Dynamics of Phaeocystis pouchetii blooms in the Wadden Sea of Sylt (German Bight, North Sea). - Estuar. coast. Shelf Sci. 23, 171-182.

Wulff, A., 1935. Uber Hydrographie und Oberflächenplankton nebst Verbreitung von Phaeocystis in der Deutschen Bucht im Mai 1933. - Ber. dt. wiss. Kommn Meeresforsch. 8 (3), 343-350. 